\title{
Functional analysis of the Bacillus subtilis purT gene encoding formate-dependent glycinamide ribonucleotide transformylase
}

\author{
Hans H. Saxild, ${ }^{1}$ Jan H. Jacobsen' + and Per Nygaard ${ }^{2}$ \\ Author for correspondence: Hans Saxild. Tel: +454525 2494. Fax: +4545882660 . \\ e-mail: hhs@lm.dtu.dk
}

\footnotetext{
1 Department of Microbiology, Technical University of Denmark, DK-2800 Lyngby, Denmark

2 Department of Biological Chemistry, University of Copenhagen, DK-1307 Copenhagen, Denmark
}

\begin{abstract}
The purT gene from Bacillus subtilis encoding the formate-dependent glycinamide ribonucleotide transformylase $T$ was cloned by functional complementation of an Escherichia coli purN purT double mutant. The nucleotide sequence revealed an open reading frame of 384 amino acids. The purt amino acid sequence showed similarity to the enzyme phosphoribosylaminoimidazole carboxylase encoded by the purK gene but not to the $\boldsymbol{N}^{10}$-formyltetrahydrofolate-dependent glycinamide ribonucleotide transformylase $\mathbf{N}$ enzyme encoded by the purN gene. The glycinamide ribonucleotide transformylase $\mathrm{T}$ level was repressed in cells grown in rich medium compared to minimal-medium-grown cells. However, when the culture entered the stationary-growth phase the enzyme level increased in rich medium and decreased in minimal medium. By comparing the deduced amino acid sequence of the $B$. subtilis purT gene product with translated nucleotide sequences in various databanks, evidence for the existence of putative purT genes in the Gram-negative bacteria Pasteurella haemolytica and Pseudomonas aeruginosa was obtained.
\end{abstract}

Keywords: 5 '-phosphoribosylglycinamide transformylase, growth phase, pur $T$ gene sequence, $p u r T$ gene expression, purT-lac $Z$ gene fusion

\section{INTRODUCTION}

The de novo synthesis of inosine monophosphate (IMP) proceeds by a 11-step pathway. The third step is the formylation of glycinamide ribonucleotide (GAR) to formylglycinamide ribonucleotide (formyl-GAR). In Escherichia coli and Bacillus subtilis this reaction is catalysed by two different enzymes; the $N^{10}$-formyltetrahydrofolate $\left(N^{10}\right.$-formyl-THFA)-dependent GAR transformylase $\mathrm{N}$ and the formate-dependent GAR transformylase T, which are encoded by the $\operatorname{pur} N$ and $p u r T$ genes, respectively (Smith \& Daum, 1987; Ebbole \& Zalkin, 1987; Nygaard \& Smith, 1993; Saxild et al., 1994a). In B. subtilis the purN gene is located in the 12-gene pur operon, which encodes all enzymes necessary for the biosynthesis of IMP. The

\footnotetext{
† Present address: Novo Nordic, Plant Protection Division, Hillerødgade 33, DK-2400 Copenhagen NV, Denmark.
}

Abbreviations: GAR, glycinamide ribonucleotide; IMP, inosine monophosphate.

The EMBL accession number for the sequence data reported in this paper is X78962. level of the purine biosynthetic enzymes is decreased when purine compounds are added to the growth medium (Saxild \& Nygaard, 1991). This repression is achieved by a transcription termination-antitermination mechanism (Ebbole \& Zalkin, 1989). The purT gene maps between the cys $A$ and aroI markers at $20^{\circ}$ on the linkage map. No significant repression of the purT gene expression by purines has been observed (Saxild et al., 1994a). In contrast, the expression of the E. coli purT gene is transcriptionally regulated by the PurR repressor protein and hypoxanthine/guanine (Meng \& Nygaard, 1990; Nygaard \& Smith, 1993). In purN mutants, in which growth is dependent on PurT activity, growth in purinefree medium is reduced and is inhibited by glycine (Nygaard \& Smith, 1993; Saxild et al., 1994a). Recently, a gene, pur $U$, which encodes a $N^{10}$-formyltetrahydrofolate hydrolase that cleaves $N^{10}$-formyltetrahydrofolate into formate and tetrahydrofolate, was identified in $E$. coli (Nagy et al., 1993). It appears that PurU provides the major source of formate for the PurT-catalysed reaction under aerobic conditions, and that this reaction is inhibited by glycine. This explains why growth of $\operatorname{purN}$ mutants is inhibited by glycine. 
In this report we describe the molecular cloning and nucleotide sequence of the $B$. subtilis pur $T$ gene. Also the identification of the transcriptional start site and of the $p u r T$ promoter and studies of $p u r T$ gene expression are reported.

\section{METHODS}

Bacterial strains, plasmids and growth conditions. The bacterial strains and plasmids used are listed in Table 1. Growth in liquid medium at $37^{\circ} \mathrm{C}$ was followed by measuring $\mathrm{OD}_{450}$. As minimal medium for $B$. subtilis, the Spizizen salt-buffered medium was used (Saxild \& Nygaard, 1987); for E. coli, a phosphate-buffered salt medium was used (Monod et al., 1951). Both media were supplemented with thiamin- $\mathrm{HCl}\left(1 \mu \mathrm{g} \mathrm{ml}^{-1}\right)$, and amino acids $\left(50 \mu \mathrm{g} \mathrm{ml}^{-1}\right)$ and hypoxanthine $\left(45 \mu \mathrm{g} \mathrm{ml}^{-1}\right)$ were added to auxotrophic strains when required. L-broth was used as a rich medium. Antibiotics were used at the following concentrations: ampicillin (Ap), $100 \mu \mathrm{g} \mathrm{ml}^{-1}$; tetracycline (Tc), $8 \mu \mathrm{g} \mathrm{ml}^{-1}$; chloramphenicol $(\mathrm{Cm}), 5 \mu \mathrm{g} \mathrm{ml}^{-1}$; and neomycin (Neo), $5 \mu \mathrm{g} \mathrm{ml}^{-1}$.

DNA manipulations and genetic techniques. Chromosomal DNA from B. subtilis was isolated according to the method of Saxild \& Nygaard (1987). Small-scale plasmid preparations from E. coli were prepared as described by Birnboim \& Doly (1979). Large-scale plasmid preparations from E. coli were isolated from $200 \mathrm{ml}$ L-broth cultures. Transformation (Boylan et al., 1972) and transduction (Love et al., 1976) of B. subtilis and transformation of $E$. coli (Hanahan, 1983) have previously been described by Saxild \& Nygaard $(1987,1988)$. For transduction the generalized transducing phage AR9 was used, which is related to the phage PBS1 (Love et al., 1976). Treatment of DNA with restriction enzymes (Boehringer Mannheim), T4 DNA ligase and Klenow polymerase (Gibco-BRL) was performed as recommended by the suppliers.

Southern blot analysis. DNA was blotted onto a nitrocellulose membrane (GeneScreen, NEN Research Products). The DIG DNA Labelling and Detection kit (Boehringer Mannheim) was used for colorimetric detection of the hybridization products. The recipe supplied by the manufacturer was followed.

DNA sequencing. DNA sequence was obtained by the chaintermination reaction method using dideoxyribonucleotides as described by Sanger et al. (1977). All sequencing analysis was done on double-stranded plasmid DNA templates.

Primer extension analysis. RNA from $B$. subtilis was isolated according to the method of Resnekov et al. (1990) with some modifications. Cells were grown in minimal medium to an $\mathrm{OD}_{450}$ of $1 \cdot 0$. The culture $(20 \mathrm{ml})$ was poured into crushed ice and centrifuged for $5 \mathrm{~min}$ at $7000 \mathrm{~g}$. Cells were washed three times in $1 \mathrm{ml}$ ice-cold buffer $(50 \mathrm{mM}$ Tris/ $\mathrm{HCl}, \mathrm{pH} 7 \cdot 5 ; 50 \mathrm{mM}$ $\mathrm{NaCl} ; 5 \mathrm{mM}$ EDTA) and transferred to an Eppendorf microcentrifuge tube. The cells were treated with lysozyme by resuspension in $200 \mu \mathrm{l}$ buffer $(20 \mathrm{mM}$ sodium maleate, $\mathrm{pH} 6.5$; $0.5 \mathrm{M}$ sucrose; $20 \mathrm{mM} \mathrm{MgCl}_{2}$ ) containing $3.5 \mathrm{mg}^{\text {lysozyme ml}} \mathrm{m}^{-1}$ followed by incubation on ice for $30 \mathrm{~min}$. The following reagents were then added: $200 \mu \mathrm{l} 0 \cdot 1 \mathrm{M}$ sodium acetate, $\mathrm{pH} 4 \cdot 0$, containing $2 \%(\mathrm{w} / \mathrm{v})$ SDS; $10 \mu \mathrm{l} 0.5 \mathrm{M}$ EDTA, $\mathrm{pH} 8.0$; and RNase inhibitors $(4 \mu \mathrm{l} 1 \%$, w/v, heparin; $1 \mu \mathrm{l} 1 \mathrm{M}$ phenanthrolin). The cells were lysed by heating to $65^{\circ} \mathrm{C}$ for $3 \mathrm{~min}$. Proteinase $\mathrm{K}\left(20 \mathrm{mg} \mathrm{ml}^{-1} ; 40 \mu \mathrm{l}\right)$ was added and incubation continued for $5 \mathrm{~min}$ on ice. The lysate was treated with $400 \mu \mathrm{l}$ hot $\left(65^{\circ} \mathrm{C}\right)$ phenol for $3 \mathrm{~min}$ and the two phases were separated by centrifugation for $5 \mathrm{~min}$. The upper phase containing the nucleic acids was transferred to a new tube and the phenol extraction was repeated. The aqueous phase was then extracted with buffered (10 mM Tris/HCl, pH 8.0; $1 \mathrm{mM}$ EDTA) phenol/chloroform $(1: 1, \mathrm{v} / \mathrm{v})$ at room temperature. Nucleic acid was precipitated by adding $3 \mathrm{M}$ sodium acetate, $\mathrm{pH} 4 \cdot 8(0 \cdot 1$ vol.), and $96 \%$ (v/v) ethanol ( 2 vols) followed by centrifugation for $10 \mathrm{~min}$. The pellet was washed with $70 \%(\mathrm{v} / \mathrm{v})$ ethanol and dried and resuspended in $90 \mu \mathrm{l} \mathrm{H}_{2} \mathrm{O}$. The solution was heated to $80^{\circ} \mathrm{C}$ for $2 \mathrm{~min}$ and then placed on ice. DNA was removed by adding the following reagents: $10 \mu \mathrm{l}$ buffer $(250 \mathrm{mM} \mathrm{KCl}$; $25 \mathrm{mM} \mathrm{MgCl}$; $500 \mathrm{mM}$ Tris/HCl, pH 6.7), 40 units RNasin (Promega) and 30 units DNase I (RNase-free) from Boehringer Mannheim. After $10 \mathrm{~min}$ incubation at room temperature, the solution was extracted twice with phenol/chloroform and once with chloroform, and RNA was precipitated with sodium acetate and ethanol as described above. The dried pellet was resuspended in $100 \mu \mathrm{l} 10 \mathrm{mM}$ potassium phosphate, $\mathrm{pH} 6.5$, and stored at $-20^{\circ} \mathrm{C}$. This procedure normally gives approximately $100 \mu \mathrm{g}$ RNA. The single-stranded DNA primer used for primer extension was labelled with $\left.{ }^{32} \mathrm{P}\right]$ phosphate at the $5^{\prime}$ terminus using T4 polynucleotide kinase and $\left[\gamma^{32} \mathrm{P}\right] \mathrm{ATP}$. The primer extension reaction was performed as described by Sambrook $e t$ al. (1989) with the following modifications. RNA $(20-40 \mu \mathrm{g})$ in phosphate storage buffer $(10 \mu \mathrm{l})$ was mixed with approximately 1 pmol $(1 \mu \mathrm{l})$ radiolabelled DNA primer. The mixture was heated to $70^{\circ} \mathrm{C}$ for $10 \mathrm{~min}$ and placed on ice, then $4 \mu \mathrm{l}$ reaction buffer $(250 \mathrm{mM}$ Tris/HCl, pH 8.3; $375 \mathrm{mM} \mathrm{KCl} ; 15 \mathrm{mM}$ $\left.\mathrm{MgCl}_{2}\right), 2 \mu \mathrm{l} 0 \cdot 1 \mathrm{M}$ DTT, $1 \mu \mathrm{dNTP}(10 \mathrm{mM}$ concentration each) and $2 \mu \mathrm{H}_{2} \mathrm{O}$ were added. After incubation for $2 \mathrm{~min}$ at $37^{\circ} \mathrm{C}, 200$ units of reverse transcriptase was added and the incubation continued for $1 \mathrm{~h}$. The radiolabelled cDNA products were separated on a $6 \%(\mathrm{w} / \mathrm{v})$ polyacrylamide sequencing gel and visualized by autoradiography.

Enzyme assays. Preparation of cell-free extracts for enzyme measurements has previously been described by Saxild \& Nygaard (1988). Detection of $\alpha$-amylase activity in B. subtilis cells was performed by spraying colonies grown on L-broth agar plates containing $1 \%(\mathrm{w} / \mathrm{v})$ starch with a solution of $0.5 \%$ iodine and $1 \%(\mathrm{w} / \mathrm{v})$ potassium iodide. The $\alpha$-amylaseproducing colonies formed a clear halo, whereas the $\alpha$-amylasenegative colonies did not. The catechol-2,3-dioxygenase (XylE) activity in B. subtilis cells was screened by spraying colonies grown on minimal medium agar plates with a solution of $0.5 \mathrm{M}$ catechol. $\mathrm{XylE}^{+}$colonies became yellow, whereas $\mathrm{XylE}^{-}$ colonies did not. Formate-dependent GAR transformylase T activity was determined according to Nygaard \& Smith (1993). GAR synthetase and hypoxanthine phosphoribosyltransferase activities were determined as described before (Saxild \& Nygaard, 1991, 1988). One unit is defined as $1 \mathrm{nmol}$ substrate converted $\mathrm{min}^{-1}$ at $37^{\circ} \mathrm{C}$. Determination of $\beta$-galactosidase activity (Miller, 1972) was performed according to Saxild $e$ al. (1994b). Protein was determined by the Lowry method.

\section{RESULTS}

\section{Cloning and genetic characterization of the B. subtilis purt gene}

The $B$. subtilis purT gene was cloned by functional complementation in E. coli. The E. coli purine auxotrophic strain TX680 (purN purT) was transformed with a genome library of EcoRI restriction fragments from $B$. subtilis strain HH124 (pur $N$ ) cloned into plasmid pLNA2, which confers $\mathrm{Tc}^{\mathbf{R}}$ in E. coli. By using DNA from strain $\mathrm{HH} 124$, cloning of the $p u r N$ gene was avoided. In one 
Table 1. Bacterial strains and plasmids

BGSC, Bacillus Genetic Stock Center, Columbus, Ohio, USA; Ap, ampicillin; Tc, tetracycline; Cm, chloramphenicol; Neo, neomycin.

\begin{tabular}{|c|c|c|}
\hline Strain/plasmid & Characteristics & Source or reference \\
\hline \multicolumn{3}{|l|}{ B. subtilis } \\
\hline 168 & $\operatorname{trp} C 2$ & BGSC \\
\hline QB928 & $\operatorname{trp} C 2$ aroI96 dal-1 purB33 & BGSC \\
\hline QB944 & $\operatorname{trp} C 2$ cys $A 14$ pur $A 16$ & BGSC \\
\hline $\mathrm{HH} 123$ & $\operatorname{trp} C 2$ bis $A 1$ & Saxild et al. (1994a) \\
\hline HH124 & $\operatorname{trp} C 2$ bis. $A 1$ purN-602 & Saxild et al. (1994a) \\
\hline HH179 & $\operatorname{trp} C 2$ bis $A 1$ purN-602 purT-46 & Saxild et al. (1994a) \\
\hline $\mathrm{HH} 202$ & $\operatorname{trpC} 2$ bis $A 1$ purN-602 purT-46::pHJ3 (pur $\left.T^{+}\right)$(cat) & Transformation of $\mathrm{HH} 179$ by $\mathrm{pHJ} 3, \mathrm{Cm}^{\mathrm{R}}$ \\
\hline HH208 & $\operatorname{trp} C 2$ amyE ::purT-lacZ (neo) & $\begin{array}{l}\text { Transformation of } 168 \text { by } \mathrm{pHH} 1009 \\
\text { digested with } \mathrm{XhoI}, \mathrm{Neo}^{\mathrm{R}}\end{array}$ \\
\hline \multicolumn{3}{|l|}{ E. coli } \\
\hline MT102 & $\begin{array}{l}\mathrm{F}^{-} \text {araD139 } \Delta(\operatorname{argF}-\text { leu }) 7696 \Delta(\text { lac }) X 74 \text { galU galK bsdR2 } \\
\left(\mathrm{r}^{-} \mathrm{m}^{+}\right) m c r B 1 \operatorname{rpsL}\left(\mathrm{Str}^{\mathrm{R}}\right)\end{array}$ & Laboratory stock \\
\hline TX680 & $\begin{array}{l}\text { ara } \Delta(\text { gpt-pro-lac) thi rbs-221 ilvB2102 ilvHI2202 } \\
\text { pur } N^{\prime}-l a c Z^{+} Y^{+}:: \operatorname{Kan}^{\mathrm{R}} \text { purT }\end{array}$ & Smith \& Nygaard (1993) \\
\hline \multicolumn{3}{|l|}{ Plasmid } \\
\hline $\mathrm{pKS}+$ & Ap & Stratagene \\
\hline pAMB22 & $\mathrm{Tc} \mathrm{Cm}$ & Zukowski \& Miller (1986) \\
\hline pC194 & $\mathrm{Cm}$ & BGSC \\
\hline pUN121 & Ap Tc & Nilsson et al. (1983) \\
\hline pDG268neo & $\begin{array}{l}\text { Ap Neo. pBR322 derivative containing the } B \text {. subtilis amyE gene } \\
\text { in which a promoterless lac } Z \text { gene and a DNA cassette } \\
\text { containing the neo gene have been inserted. Transcriptional } \\
\text { fusions can be obtained by inserting DNA fragments into a } \\
\text { unique HindIII site in front of the lac } Z \text { gene. }\end{array}$ & C. W. Price* \\
\hline pLNA2 & $\begin{array}{l}\text { pUN121 partially digested with } P_{s t} \mathrm{I} \text {, blunt-ended with Klenow } \\
\text { polymerase and ligated with a } 1.6 \mathrm{~kb} \text { blunt-ended ClaI } \\
\text { fragment of pC194 containing the cat gene }\end{array}$ & L. N. Nonboet \\
\hline $\mathrm{pHJ3}$ & $\begin{array}{l}\text { pLNA2 containing the } B . \text { subtilis purT gene on a } 6 \mathrm{~kb} \text { EcoRI } \\
\text { fragment }\end{array}$ & This work \\
\hline $\mathrm{pHJ} 4$ & $\begin{array}{l}\mathrm{pKS}+\text { digested with PstI ligated to a } 3.4 \mathrm{~kb} \text { Pst I fragment from } \\
\mathrm{pHJ} 3 \text { containing the purT gene }\end{array}$ & This work \\
\hline $\mathrm{pHJ} 8$ & Deletion of a 500 bp HindIII fragment from $\mathrm{pHJ} 4$ & This work \\
\hline $\mathrm{pHJ} 14$ & $\begin{array}{l}\text { pAMB22 digested with } S m a \mathrm{I}+\text { EcoRI ligated with a } 355 \mathrm{bp} \\
\text { EcoRI-HincII fragment from } \mathrm{pHJ} 4 \text { containing the purT } \\
\text { promoter }\end{array}$ & This work \\
\hline pHJ16 & $\begin{array}{l}\text { pAMB22 digested with } S_{m a I}+E c o \text { RI ligated with a } 260 \text { bp } \\
E c o \text { R }-S_{s p I} \text { fragment from } \mathrm{pHJ} 4 \text { containing the purT promoter } \\
\text { lacking the }-10 \text { region }\end{array}$ & This work \\
\hline pHH1009 & $\begin{array}{l}\text { pDG268neo digested with HindIII ligated with a } 500 \text { bp HindIII } \\
\text { fragment from } \mathrm{pHJ} 4 \text { containing the purT promoter }\end{array}$ & This work \\
\hline
\end{tabular}

*C. W. Price, Department of Food Science and Technology, University of California, Davis, California, USA.

† L. N. Nonboe, GeneExpress, Novo Nordic, Symbion, Fruebjergvej 3, DK-2100, Copenhagen, Denmark.

experiment six $\mathrm{Tc}^{\mathbf{R}}$ transformants appeared on purinefree minimal medium agar plates. Transformation of strain TX680 with the same amount of DNA resulted in approximately $7000 \mathrm{Tc}^{\mathbf{R}}$ transformants on minimal medium agar plates. The plasmids from the TX680 $\mathrm{Pur}^{+}$ clones were isolated and all contained a $6 \mathrm{~kb}$ EcoRI fragment cloned in pLNA2. One of the plasmids was chosen and named $\mathrm{pHJ} 3$. The ability to complement the purine deficiency of strain TX680 was preserved when the orientation of the EcoRI insert in $\mathrm{pHJ} 3$ was reversed (data not shown). This indicated that the pur $T$ gene was most likely expressed from an internal promoter. Cell-free extracts of TX680 harbouring $\mathrm{pHJ} 3$ grown in LB medium contained 22 units (mg protein) ${ }^{-1}$ GAR transformylase $T$ activity. The purT gene was subcloned into plasmid pBluescript KS + on a $3.4 \mathrm{~kb}$ Pst I fragment ( $\mathrm{pHJ} 4$ ). 
PotI

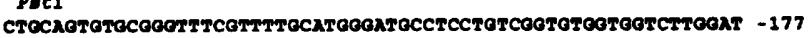

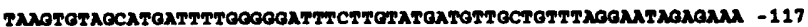

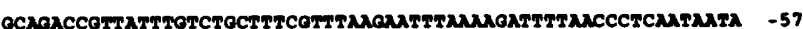

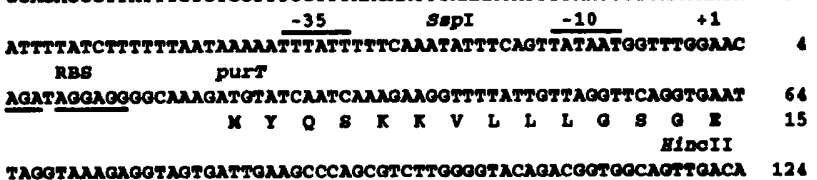

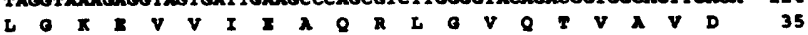

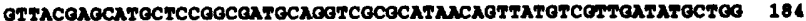

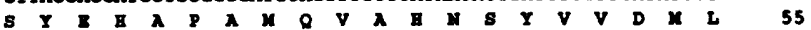

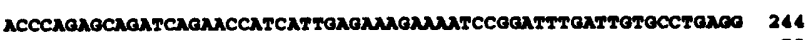
D P I BIndiII

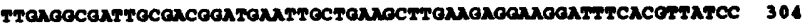
Y I I A T D I L I K I I I I O F I V I

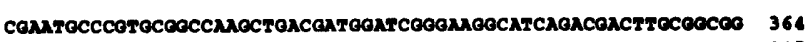

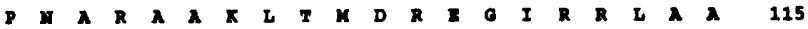

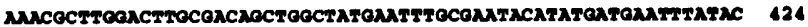
I I L G L A T A C Y I F A M T Y D I F I 135

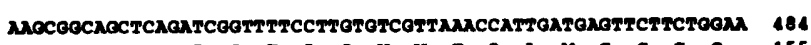

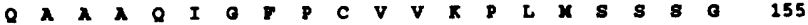

MAOCCAMATOTOTOCCOCTCTONAOCOOATTTAGAOAOCTOCTOOGAOACOOCOATCO 544

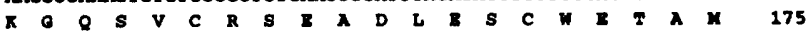

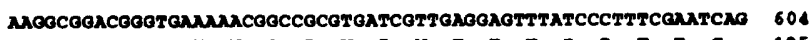

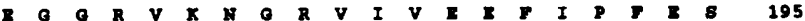

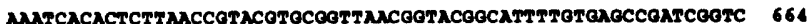

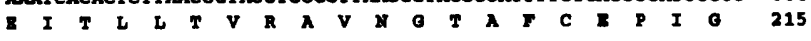

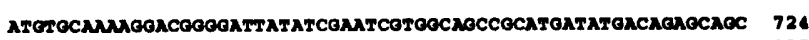

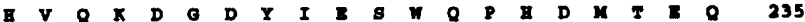

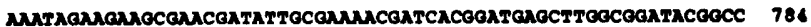
Q I I I I V D I A K I I T D I L O O Y O

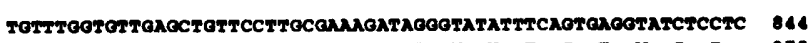

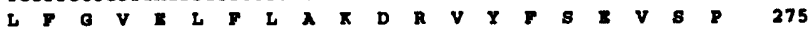

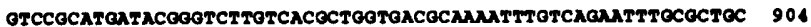
$\begin{array}{lllllllllllllllllllll}\text { R P } & \text { I } & \text { D } & \text { T } & \text { O } & \text { L } & \text { V } & \text { T } & \text { L } & \text { V } & \text { T } & \text { Q } & \text { N } & \text { L } & \text { S } & \text { I } & \text { F } & \text { A } & \text { L } & 295\end{array}$

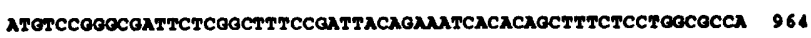
$\begin{array}{lllllllllllllllllllll} & \text { B } & \text { R } & \text { A } & \text { I } & \text { L } & \text { O } & \text { F } & \text { P } & \text { I } & \text { T } & \text { E } & \text { I } & \text { T } & \text { Q } & \text { L } & \text { S } & \text { P } & \text { G } & \text { A } & 315\end{array}$

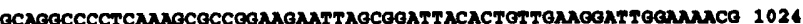
S R P L I A P I E I A A

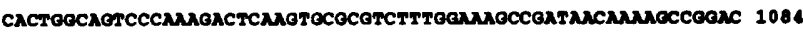

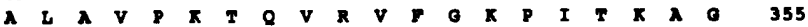

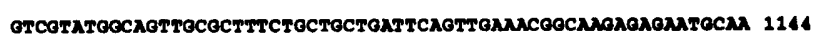

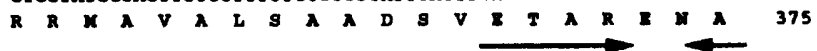

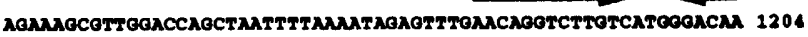

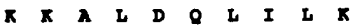

384

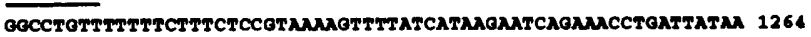
CIaI mpr

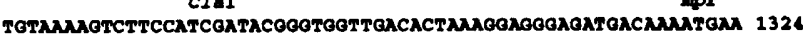

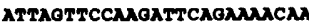

L $V$ P $R$ F $R$ R $\times \quad \mathbf{2}$ 1349

Fig. 1. Nucleotide and deduced amino acid sequences of the purT gene encoding GAR transformylase $T$. The purT promoter elements are indicated by lines above the sequence. The putative ribosome-binding site (RBS) is underlined. A stem and loop structure specifying a potential rho-independent transcription terminator is indicated by arrows above the sequence. The nucleotide beneath the plus sign is the first nucleotide of the purT messenger. mpr encodes an extracellular metalloprotease (Sloma et al., 1990).
Deletion of $500 \mathrm{bp}$ from one end of the $3.4 \mathrm{~kb}$ Pst $\mathrm{I}$ fragment ( $\mathrm{pHJ} 8$; Table 1) resulted in the loss of purT complementation ability, indicating that either the start or the end of the purT gene was located in this region. Plasmid $\mathrm{pHJ} 3$ was transformed into the purine auxotrophic B. subtilis strain HH179 (purN purT) selecting for $\mathrm{Cm}^{\mathrm{R}}$. Since plasmids derived from pLNA2 cannot replicate in B. subtilis, $\mathrm{Cm}^{\mathbf{R}}$ transformants could only be formed if the plasmid integrated into the chromosome by a single crossing-over event in the pur $T$ region. All the tested $\mathrm{Cm}^{\mathrm{R}}$ transformants had a purine prototrophic phenotype. A transducing AR9 lysate was made from one of the $\mathrm{Cm}^{\mathrm{R}}$ transformants (HH202) and was used for transduction in two of the Dedonder mapping kit strains, QB944 (cys A) and QB928 (arol) (Dedonder et al., 1977), by selecting $\mathrm{Cm}^{\mathrm{R}}$ transductants. Twenty-seven $\mathrm{CysA}^{+}$ clones were found among $138 \mathrm{Cm}^{\mathrm{R}} \mathrm{QB} 944$ transductants and $59 \mathrm{AroI}^{+}$clones found among $138 \mathrm{Cm}^{\mathrm{R}} \mathrm{QB} 928$ transductants. These frequencies are in good agreement with the previously reported location of the purT gene between $c y s A$ and aroI on the linkage map (Saxild et al., 1994a).

\section{Nucleotide and derived amino acid sequence}

Deletion analysis of the cloned DNA led to the identification of the purT gene on a $1.5 \mathrm{~kb}$ Pst $\mathrm{I}-\mathrm{ClaI}$ fragment. The nucleotide sequence of both strands of the $1.5 \mathrm{~kb}$ PstI-ClaI fragment was determined and the nucleotide sequence of the purT gene is shown in Fig. 1. The purT gene contained an open reading frame of $1152 \mathrm{bp}$ which gives a protein of 384 amino acids. Three potential translational start codons in the $\mathrm{N}$-terminal part of the pur $T$ reading frame were found, one 126 nucleotides and another 159 nucleotides downstream from the ATG start codon shown in Fig. 1. The ATG at position +22 is the most likely translation start site (i) because of the position of a potential Shine-Dalgarno sequence, and (ii) from comparison with the E. coli and Pasteurella baemolytica purT sequences (see Discussion). Immediately downstream of the pur $T$ gene we located the $m p r$ gene encoding an extracellular metalloprotease (Sloma et al., 1990).

\section{Mapping of the purT promoter region and the $5^{\prime}$ end of the purT transcript}

Putative $\sigma \mathrm{A}-35$ and -10 regions preceded the purT structural gene. The upstream DNA sequence was screened for promoter activity by inserting the PstIHincll fragment (nucleotides -237 to +118 in Fig. 1) from $\mathrm{pHJ} 4$ in front of the promoterless $x y / E$ gene of pAMB22 (pHJ14). A similar plasmid ( $\mathrm{pHJ16}$ ) containing the PstI-SspI fragment (nucleotides -237 to -23 ) was also constructed (Table 1). Strain $\mathrm{HH} 123$ was $\mathrm{XylE}^{+}$ when it contained $\mathrm{pHJ} 14$, and $\mathrm{XylE}^{-}$when it contained $\mathrm{pHJ} 16$. These results showed that a promoter was situated immediately upstream of the purT structural gene.

Primer extension using reverse transcriptase enzyme was used to map the $5^{\prime}$ end of the purT mRNA isolated from strain $\mathrm{HH} 123$. A primer complementary to the nucleotide 


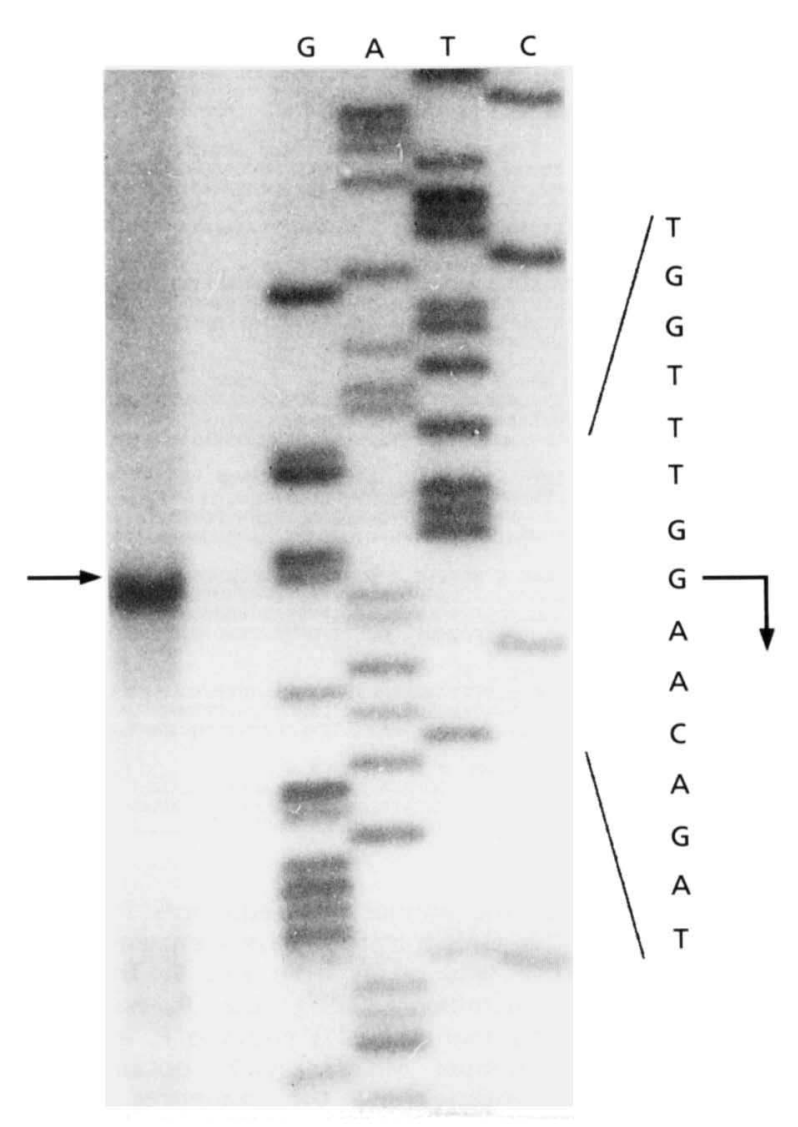

Fig. 2. Primer extension analysis of the purT transcription start site. The primer annealed to nucleotides +67 to +95 . The dideoxy-sequencing ladder was obtained with the same primer used for CDNA synthesis. RNA was isolated from wild-type strain HH123. The position corresponding to the start of transcription is marked by an arrow.

sequence from +67 to +95 was used. Fig. 2 shows the result of the primer extension experiment. The same primer was used to generate the sequencing ladder. The start site of transcription, which is numbered +1 , was located 21 nucleotides upstream of the putative translational start codon.

\section{Expression of the purT gene}

purT gene expression was determined by measuring GAR transformylase $T$ activity and $\beta$-galactosidase activity from a transcriptional fusion. The construction of a transcriptional fusion between the $\operatorname{pur} T$ promoter region and the E. coli lac $Z$ reporter gene in the plasmid vector pDG268neo is described in Table 1. The resulting plasmid, pHH1009, was linearized with $X b o I$, which cuts the DNA outside of the amyE-neo-lac $Z$ region, and transformed into $B$. subtilis strain 168 selecting for $\mathrm{Neo}^{\mathbf{R}}$. Since the neo gene and the purT-lac $Z$ fusion gene were flanked by sequences of the amy $E$ gene (encoding $\alpha$ amylase), $\mathrm{Neo}^{\mathrm{k}}$ transformants resulted from a double crossing-over event in the amyE gene. This produced a disrupted amyE gene which now contained the neo gene and the purT-lacZ fusion. Two $\alpha$-amylase-deficient Neo $^{\mathbf{R}}$ transformants were purified and their chromosomal DNA subjected to a Southern blot analysis. They both contained a single copy integration of the purT-lac $Z$ fusion into the amyE gene (data not shown). One of the strains was named HH208 [purT-lac $\left.:: a m y E\left(\mathrm{Neo}^{\mathrm{R}}\right)\right]$. Strain $\mathrm{HH} 208$ was grown in minimal medium and in L-broth medium. The expression of the purT gene was determined by measuring GAR transformylase $T$ activity and by measuring $\beta$-galactosidase from the transcriptional fusion (Table 2). For comparison we included the determination of levels of two other purine enzymes involved in IMP synthesis; GAR synthetase, encoded by the purD gene located within the pur operon, and hypoxanthine phosphoribosyltransferase, encoded by the $b p t$ gene. In cells grown in minimal medium a reduced level of GAR transformylase $T$ activity was seen when cells entered the stationary growth phase but transcription, as judged from the level of $\beta$-galactosidase activity, was not reduced, perhaps indicating some kind of inactivation of the enzyme. The addition of hypoxanthine to the minimal medium had no effect on purT gene expression. The level of GAR synthetase paralleled that of GAR transformylase

\section{Table 2. Effects of growth stage on the expression of purine genes}

Strain HH208 was grown in minimal medium with and without hypoxanthine $\left(\mathrm{Hx} ; 45 \mu \mathrm{g} \mathrm{ml}^{-1}\right)$, and in L-broth. Cells were harvested in the exponential phase, and in the stationary phase $2-3 \mathrm{~h}$ after they had left the exponential-growth phase. Enzyme activities $( \pm \mathrm{sD})$ were determined as described in Methods. PurT, GAR transformylase T; PurT-LacZ, $\beta$-galactosidase produced by the transcriptional purT-lacZ fusion; PurD, GAR synthetase; Hpt, hypoxanthine phosphoribosyltransferase.

\begin{tabular}{|c|c|c|c|c|c|}
\hline \multirow[t]{2}{*}{ Growth medium } & \multirow[t]{2}{*}{ Growth phase } & \multicolumn{4}{|c|}{ Enzyme activity [U (mg protein) ${ }^{-1}$ ] } \\
\hline & & PurT & PurT-LacZ & PurD & Hpt \\
\hline \multirow[t]{2}{*}{ Minimal } & Exponential & $37 \pm 12$ & $48 \pm 3$ & $42 \pm 8$ & $95 \pm 11$ \\
\hline & Stationary & $16 \pm 7$ & $55 \pm 8$ & $16 \pm 4$ & $102 \pm 33$ \\
\hline \multirow[t]{2}{*}{ Minimal $+\mathrm{Hx}$} & Exponential & $33 \pm 8$ & $48 \pm 8$ & $15 \pm 8$ & $154 \pm 4$ \\
\hline & Stationary & $10 \pm 2$ & $49 \pm 6$ & $3 \pm 1$ & $168 \pm 15$ \\
\hline \multirow[t]{2}{*}{ L-broth } & Exponential & $9 \pm 5$ & $6 \pm 2$ & $3 \pm 2$ & $220 \pm 4$ \\
\hline & Stationary & $20 \pm 5$ & $21 \pm 4$ & $18 \pm 1$ & $143 \pm 45$ \\
\hline
\end{tabular}


$T$ except for the overall reduction in enzyme level in hypoxanthine-supplemented medium. The level of hypoxanthine phosphoribosyltransferase, in contrast, was not affected by the growth phase but was slightly elevated in the hypoxanthine-supplemented growth medium. When cells grown in rich medium (L-broth) entered the stationary phase a reversed pattern was seen; both GAR transformylase $T$ and GAR synthetase activity increased as $\operatorname{did}$ purT gene transcription, while the level of hypoxanthine phosphoribosyltransferase, which was higher in rich medium, was hardly affected by the change in growth phase. Several attempts to find the compounds that are responsible for the repression of purT expression in rich medium failed; this included the addition of various combinations of amino acids dependent on onecarbon metabolism and of adenine, guanine and formate to the growth medium.

\section{DISCUSSION}

The B. subtilis pur $T$ gene was cloned and its nucleotide sequence determined. The pur $T$ gene is most likely a monocistronic transcriptional unit, based on the following. (i) A start site for transcription was located to a position 21 nucleotides upstream of the start site for translational initiation of a 384 amino acid open reading frame. (ii) The +1 position is preceded by a potential $\sigma A$ promoter sequence: (-34)TTTATT-N 16 -TATAAT $(-7)$. (iii) Fusion to a promoterless $x y l E$ gene at a $S s p \mathrm{I}$ restriction site situated between the -35 and -10 regions resulted in the loss of promoter activity whereas fusions to a distal point gave a $x y l E^{+}$phenotype. (iv) A potential secondary structure for a rho-independent transcription termination was found immediately downstream from the translational stop site. The $\Delta G$ value for this stem-loop structure was calculated to be $-18 \mathrm{kcal}$ $\mathrm{mol}^{-1}\left(-75 \cdot 6 \mathrm{~kJ} \mathrm{~mol}^{-1}\right.$ ) (Tinoco et al., 1973).

The expression of the purT gene in B. subtilis is not affected by purine bases in the growth medium (Saxild $e t$ al., 1994a) as are the other pur genes (Saxild \& Nygaard, 1991), and the purT control region has no sequence similarity or structural features (operator sites or secondary structures) in common with the promoter regions of the $B$. subtilis gua $A$, gua $B$ or pur $A$ genes or the pur operon. However, we have now provided evidence for the regulation of the cellular level of GAR transformylase $T$. The expression of the purT gene and the synthesis of GAR transformylase $T$, like that of the GAR synthetase, is reduced in rich medium and is affected by the growth phase, resulting in low enzyme levels in the exponential phase and higher levels in the stationary phase. The reversed pattern is seen in minimal medium, in which the GAR transformylase $T$ level decreases in stationary phase but the transcription is not altered. A major difference between $\operatorname{pur} T$ and $p u r D$ gene expression is the repressive effect of hypoxanthine on purD expression only (Table 2). Under all the above growth conditions the level of the purine salvage enzyme hypoxanthine phosphoribosyltransferase only varied twofold. The disappearance of GAR transformylase $T$ and GAR synthetase activity in

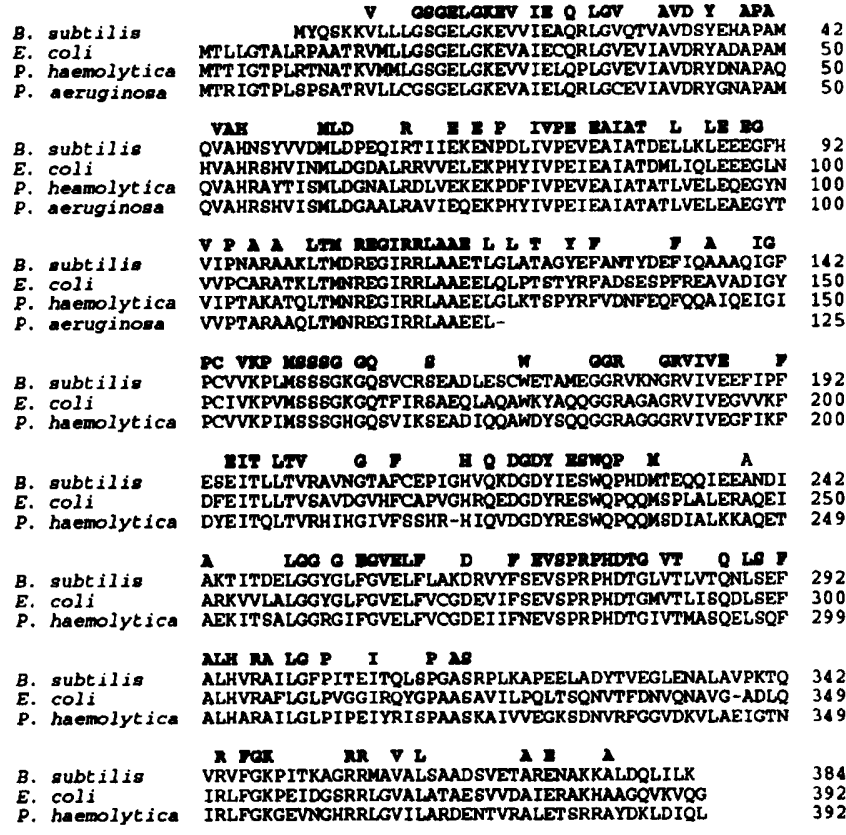
2 00 然 150 25 , tis 49 292 300 99 42 349 92

Fig. 3. Alignment of the amino acid sequences for various identified and putative GAR transformylase T enzymes. The $B$. subtilis PurT sequence was taken from Fig. 1. The $E$. coli sequence (accession number L20897), the $P$. haemolytica sequence (accession number M93021) and the $P$. aeruginosa sequence (accession number M82832) were obtained from GenBank. Residues written above the sequences represent amino acids that are identical in the $B$. subtilis, $E$. coli, $P$. aeruginosa and $P$. haemolytica sequences.

the stationary phase in cells growing in minimal medium is most likely due to enzyme inactivation, as reported for the purF gene-encoded glutamine phosphoribosylpyrophosphate amidotransferase (Ruppen \& Switzer, 1983). In contrast to this, increased synthesis of both GAR transformylase T and GAR synthetase is observed in cells grown in rich medium when entering the stationary-growth phase. We cannot at present explain why the coupling of pur $T$ gene expression and that of the pur operon, here represented by purD, is not observed when free purine bases or nucleosides are present in the growth medium.

The deduced amino acid sequence of the purT gene from $B$. subtilis was aligned with the coding sequence of the pur $T$ gene from $E$. coli and with two sequences from $P$. baemolytica and Pseudomonas aeruginosa, respectively, which both encode putative purT genes (Fig. 3). The selected initiation codon was chosen among other potential translational start sites for the following reasons: (i) a ribosome-binding site (Larsen et al., 1993), (+5)AGATAGGAGG $(+14)$, is found seven nucleotides upstream of this AUG start codon; (ii) this start site resulted in a reading frame of approximately the same length as found for the $E$. coli and the putative $P$. baemolytica reading frames (Fig. 3). It appears that the purT gene products from the various bacterial species are highly conserved (greater than $50 \%$ of identical amino 
acids). Using the BLAST algorithm (Altschul et al., 1990), the amino acid sequence of the $B$. subtilis GAR transformylase $T$ was compared to sequences available in the Swiss-Prot (release 30.0) and ProSite (release 11.0) sequence databases. The region from amino acid 102 to 117 of the B. subtilis PurT amino acid sequence is specific for PurT proteins and might be involved in the binding of GAR. This region could not be found in the $N^{\mathbf{1 0}}$-formylTHFA-dependent GAR transformylase $\mathrm{N}$ protein sequence of $B$. subtilis or $E$. coli. Several entries for the enzyme phosphoribosylaminoimidazole carboxylase from various organisms were obtained from the Swiss-Prot database. The similarity ( $27 \%$ identity) between the GAR transformylase $\mathrm{T}$ and phosphoribosylaminoimidazole carboxylase, encoded by the purK gene, has previously been reported (Marolewski et al., 1994). Two regions of $B$. subtilis PurT amino acid sequence, amino acids 5-28 and amino acids 269-283, are conserved in phosphoribosylaminoimidazole carboxylase. The database search did not result in any information that might suggest a possible function of the amino acid residues 269-283. The amino acids 5-28 region is similar to the $\mathrm{N}$-terminal part of the phosphoribosylaminoimidazole carboxylase proteins. When the PurT amino acid sequence was compared to the ProSite sequence database the same region showed similarity to the GTP-binding domain of the $\alpha$ subunit of the heterotrimeric $\mathrm{G}$ protein family (Ma et al., 1990) and to the P-loop-type ATP/GTP-binding site (Saraste et al., 1990). The $\alpha$ subunit GTP-binding domain and the Ploop site are located in the $\mathrm{N}$-terminal part of the proteins in which they occur. It is therefore possible that the Nterminal part of GAR transformylase $T$ and perhaps that of phosphoribosylaminoimidazole carboxylase are involved in binding ATP or GTP. Comparison with the ProSite database sequences identified the amino acids 140-157 region as homologous to the ATP-binding catalytic site of the enzyme carbamoyl-phosphate synthetase (CPSase). CPSase catalyses the ATP-dependent synthesis of carbamoyl phosphate from glutamine or ammonia and bicarbonate. Formation of carbamoyl phosphate proceeds through three steps. The first step is the ATP-dependent phosphorylation of bicarbonate to carboxy phosphate. This reaction is believed to take place at one of two homologous ATP-binding domains in the CPSase catalytic subunit. In the second step carboxy phosphate reacts with ammonia or an amino group from glutamine to form carbamate. The other ATP-binding site then catalyses the final phosphorylation of carbamate to carbamoyl phosphate (Simmer et al., 1990). The GAR transformylase $\mathrm{T}$ catalysed synthesis of formyl-GAR proceeds through intermediate steps similar to the first two of the CPSase-catalysed reaction. The ATP- and formate-dependent formylation of GAR to formyl-GAR has been shown to proceed through the intermediate formation of formyl phosphate via an ATP-dependent phosphorylation of formate (Marolewski et al., 1994). Formyl phosphate then reacts with the amino group on the GAR molecule to form formyl-GAR. Interestingly, the Swiss-Prot homology search also revealed that the enzyme GAR synthetase contains the same ATP-binding site. GAR synthetase catalyses the ATP-dependent syn- thesis of GAR by coupling glycine to phosphoribosylamine. While the possible function of the proposed ATPbinding site in the 5-28 region of GAR transformylase T is not obvious, we tend to believe that the $140-157$ region is a part of the ATP-binding site in which formation of formyl phosphate takes place because of similarity to sequences in other proteins which catalyse a similar reaction.

GAR transformylase $T$ activities have been found in Gram-positive and Gram-negative bacteria and in the archaea Sulfolobus sbibatae (P. Nygaard, unpublished data). Since the archaea and eukarya domains share common ancestors (Olsen \& Woese, 1993), it is possible that GAR transformylase $\mathrm{T}$ activity may also be found among eukaryotic organisms.

\section{ACKNOWLEDGEMENTS}

We wish to thank Kirsten Hansen and Jenny Steno Christensen for excellent technical assistance. This work was supported by grants from the Danish Centre for Microbiology and received financial support from the Saxild Family Foundation.

\section{REFERENCES}

Altschul, S. F., Gish, W., Miller, W., Myers, E. W. \& Lipman, D. J. (1990). Basic local alignment search tool. J Mol Biol 215, 403-410.

Birnboim, H. C. \& Doly, J. (1979). A rapid alkaline extraction procedure for screening recombinant plasmid DNA. Nucleic Acids Res 7, 1513-1523.

Boylan, R. J., Mendelson, N. H., Brooks, D. \& Young, F. E. (1972). Regulation of the bacterial cell wall: analysis of a mutant of Bacillus subtilis defective in biosynthesis of teichoic acid. J Bacteriol 110, 281-290.

Dedonder, R. A., Lepesant, J., Lepesant-Kejzlarova, J., Billault, A., Steinmetz, M. \& Kunst, F. (1977). Construction of a kit of reference strains for rapid genetic mapping in Bacillus subtilis 168. Appl Environ Microbiol 33, 989-993.

Ebbole, D. J. \& Zalkin, H. (1987). Cloning and characterization of a 12-gene cluster from Bacillus subtilis encoding nine enzymes for de novo purine nucleotide synthesis. $J$ Biol Chem 262, 8274-8287.

Ebbole, D. J. \& Zalkin, H. (1989). Bacillus subtilis pur operon expression and regulation. $J$ Bacteriol 171, 2136-2141.

Hanahan, D. (1983). Studies on transformation of Escherichia coli with plasmids. J Mol Biol 166, 557-580.

Larsen, N., Olsen, G. J., Maidak, B. L., McCauhey, M. J., Overbeek, R., Macke, T. J., Marsh, T. L. \& Woese, C. R. (1993). The ribosomal database project. Nucleic Acids Res 21, 3021-3023.

Love, E., D'Ambrosio, J. \& Brown, N. C. (1976). Mapping of the gene specifying DNA polymerase III of Bacillus subtilis. Mol \& Gen Genet 144, 313-321.

Ma, H., Yanofsky, M. F. \& Meyerowitz, E. M. (1990). Molecular cloning and characterization of GP $A 1$, a $\mathrm{G}$ protein $\alpha$ subunit gene from Arabidopsis thaliana. Proc Natl Acad Sci US A 87, 3821-3825.

Marolewski, A., Smith, J. M. \& Benkovic, S. J. (1994). Cloning and characterization of a new purine biosynthetic enzyme: a non-folate glycinamide ribonucleotide transformylase from E. coli. Biochemistry 33, 2531-2537.

Meng, L. M. \& Nygaard, P. (1990). Identification of hypoxanthine and guanine as the corepressors for the purine regulon genes of Eschericbia coli. Mol Microbiol 4, 2187-2192. 
Miller, J. H. (1972). Assay of $\beta$-galactosidase. In Experiments in Molecular Genetics, pp. 352-355. Edited by J. H. Miller. Cold Spring Harbor, NY: Cold Spring Harbor Laboratory.

Monod, J., Cohen-Bazire, J. G. \& Cohn, M. (1951). Sur la biosynthèse de la beta-galactosidase (lactase) chez Escherichia coli. La spécificité de l'induction. Biochim Biophys Acta 7, 585-599.

Nagy, P. L., McCorkle, G. M. \& Zalkin, H. (1993). purU, a source of formate for $p u r T$-dependent phosphoribosyl-N-formylglycinamide synthesis. J Bacteriol 175, 7066-7073.

Nilsson, B., Uhlen, M., Josephson, S., Gatenbeck, S. \& Philipson, L. (1983). An improved positive selection plasmid vector constructed by oligonucleotide mediated mutagenesis. Nucleic Acids Res 11, 8019-8030.

Nygaard, P. \& Smith, J. M. (1993). Evidence for a novel glycinamide ribonucleotide transformylase in Escherichia coli. J Bacteriol 175, 3591-3597.

Olsen, G. J. \& Woese, C. R. (1993). Ribosomal RNA: a key to phylogeny. FASEB J 7, 113-123.

Resnekov, O., Rutberg, L. \& von Gabain, A. (1990). Changes in the stability of specific mRNA species in response to growth stage in Bacillus subtilis. Proc Natl Acad Sci US A 87, 8355-8359.

Ruppen, M. E. \& Switzer, R. L. (1983). Involvement of the stringent response in degradation of glutamine phosphoribosylpyrophosphate amidotransferase in Bacillus subtilis. J Bacteriol 155, 56-63.

Sambrook, J., Fritsch, E. F. \& Maniatis, T. (1989). Molecular Cloning: a Laboratory Manual. Cold Spring Harbor, NY : Cold Spring Harbor Laboratory.

Sanger, F., Nicklen, S. \& Coulson, A. R. (1977). DNA sequencing with chain-terminating inhibitors. Proc Natl Acad Sci USA 74, 5463-5467.

Saraste, M., Sibbald, P. R. \& Wittinghofer, A. (1990). The P-loop - a common motif in ATP- and GTP-binding proteins. Trends Biochem Sci 15, 430-434.

Saxild, H. H. \& Nygaard, P. (1987). Genetic and physiological characterization of Bacillus subtilis mutants resistant to purine analogs. J Bacteriol 169, 2977-2983.

Saxild, H. H. \& Nygaard, P. (1988). Gene-enzyme relationships of the purine biosynthetic pathway in Bacillus subtilis. Mol \& Gen Genet 211, 160-167.

Saxild, H. H. \& Nygaard, P. (1991). Regulation of levels of purine biosynthetic enzymes in Bacillus subtilis: effects of changing nucleotide pools. J Gen Microbiol 137, 2387-2394.

Saxild, H. H., Jacobsen, J. H. \& Nygaard, P. (1994a). Genetic and physiological characterization of a formate-dependent $5^{\prime}$ phosphoribosyl-1-glycinamide transformylase activity in Bacillus subtilis. Mol \& Gen Genet 242, 415-420.

Saxild, H. H., Jensen, C. L., Hubrechts, P. \& Hammer, K. (1994b). Isolation and characterization of Bacillus subtilis genomic lac $Z$ fusions induced during partial purine starvation. J Bacteriol 176, 276-283.

Simmer, J. P., Kelly, R. E., Rinker, A. G., Scully, J. L., Jr \& Evans, D. R. (1990). Mammalian carbamyl phosphate synthetase (CPS). $J$ Biol Chem 265, 10395-10402.

Sloma, A., Rudolph, C. F., Rufo, G. A., Sullivan, B. J., Theriault, K. A., Ally, D. \& Pero, J. (1990). Gene encoding a novel extracellular metalloprotease in Bacillus subtilis. J Bacteriol 172, 1024-1029.

Smith, J. M. \& Daum, H. A., III (1987). Identification and nucleotide sequence of a gene encoding 5 '-phosphoribosylglycinamide transformylase in Escherichia coli K-12. J Biol Chem 262, 10565-10569.

Tinoco, I., Jr, Borer, P. N., Dengler, B. \& Levine, M. D. (1973). Improved estimation of secondary structure in ribonucleic acids. Nature 246, 40-41.

Zukowski, M. M. \& Miller, L. (1986). Hyperproduction of an intracellular heterologous protein in a sac $U^{\mathrm{h}}$ mutant of Bacillus subtilis. Gene 46, 247-255.

Received 1 November 1994; revised 24 February 1995; accepted 10 May 1995. 